\title{
Partial balance of $N, P$ and $K$ in a sole millet crop on a sandy loam soil of Northeast Nigeria
}

\author{
A. L. Ngala ${ }^{1 *}$, H. Yakubu ${ }^{1}$ and I. J. Tekwa ${ }^{2}$ \\ ${ }^{1}$ Department of Soil Science, University of Maiduguri, P. M. B. 1069, Maiduguri, Borno State, Nigeria. \\ ${ }^{2}$ Department of Agricultural Technology, Federal Polytechnic, P. M. B. 35, Mubi, Adamawa State, Nigeria.
}

Accepted 3 December, 2012

\begin{abstract}
A study was conducted on nutrient dynamics through partial N, P and K balances during 2005 growing season. The treatments involved three levels of farmyard manure (FYM: 2.5, 5.0 and 7.5 tons/ha) combined with half (N30P15K15 kg/ha) and full (N60P30K30 kg/ha) recommended rates of NPK fertilizer and sole recommended rates of FYM (7.5 tons/ha) and NPK (N60P30K30 kg/ha) and a control. The experiment was laid out in RCB design with three replicates. Data on nutrient inputs (fertilizers and FYM) and outputs (grains and crop residues) were estimated using the budgeted method. The treatment means were statistically compared using Duncan multiple range test (DMRT). The lowest N-balance ($44.70 \mathrm{~kg} / \mathrm{ha} /$ year) resulted from combination of lowest levels of FYM and NPK, and increased with increasing rates. Sole $7.5 \mathrm{t}$ of $\mathrm{FYM}$ resulted in positive $\mathrm{N}$-balance $(19.00 \mathrm{~kg} / \mathrm{ha} / \mathrm{year})$ compared to sole recommended rate of NPK (-2.40 kg/ha/year). P balance varied from as low as $-1.54 \mathrm{~kg} / \mathrm{ha} / \mathrm{year}$ in control to as high as $+36.16 \mathrm{~kg} / \mathrm{ha} / \mathrm{year}$ in plots which received $7.5 \mathrm{t} \mathrm{FYM}+\mathrm{N} 60 \mathrm{P} 30 \mathrm{~K} 30 \mathrm{~kg} / \mathrm{ha}$. All the treatments had negative K-balances ranging from $-6.60 \mathrm{~kg} / \mathrm{ha} / \mathrm{year}$ in plots applied with $7.5 \mathrm{t} \mathrm{FYM/ha} \mathrm{to}-108.89$ $\mathrm{kg} / \mathrm{ha} /$ year in plots which received $2.5 \mathrm{t} \mathrm{FYM/ha} \mathrm{+} \mathrm{N60P30K30} \mathrm{kg/ha,} \mathrm{depicting} \mathrm{high} \mathrm{plant} \mathrm{K-uptake}$ relative to inputs. The grain yields varied from $789 \mathrm{~kg} / \mathrm{ha}$ in control to 2440 and $2301 \mathrm{~kg} / \mathrm{ha}$ in plots applied with $7.5 \mathrm{t} \mathrm{FYM/ha} \mathrm{+} \mathrm{N60P30K30} \mathrm{kg/ha} \mathrm{and} \mathrm{7.5t} \mathrm{FYM/ha} \mathrm{+} \mathrm{N30P15K15} \mathrm{kg/ha,} \mathrm{respectively.}$ Combination of sub-optimal rates of FYM and NPK fertilizers enhanced millet yields with positive $\mathrm{N}$ and $P$ balances in the soils.
\end{abstract}

Key words: Sole millet, sandy loam soil, nutrient balance, northeast Nigeria.

\section{INTRODUCTION}

The economic growth and life quality index in the semiarid environment of northeast Nigeria largely depends on the agricultural sector, which accounts for over $25 \%$ of the gross domestic product (Nandwa, 2003). Nonetheless, the region is characterized by declining per-capita cereal production estimated at 150 to $130 \mathrm{~kg} /$ person in the past 35 years (Gichuru et al., 2003). Soil fertility depletion has been described as the single most important constraint to food security in the region. A larger proportion of the soils have low inherent fertility (Bationo et al., 1998). The major cause of soil fertility depletion is the imbalance caused by nutrients which are not commonly replaced when removed; resulting innegative nutrient balances (Gichuru et al., 2003). According to Sanchez et al. (1997), in the past 30 years, nutrient depletion was estimated at an average of $660 \mathrm{~kg}$ $\mathrm{N} / \mathrm{ha}, 75 \mathrm{~kg} \mathrm{P} / \mathrm{ha}$ and $450 \mathrm{~kg} \mathrm{~K} / \mathrm{ha}$ from about 200 million hectares of cultivated lands in 37 African counties (Nigeria inclusive). This net negative nutrient balances for African soils appear to be a contributing factor in nutrient impoverishment, reduction of agricultural productivity and the stagnation or decline in national economies. In contrast, cultivated land in temperate regions, on the average, receives nutrients in excess of those removed in 
crops, runoff, and erosion. During the same period of 30 years, the nearly 300 million ha of cultivated temperateregion soils had a net positive nutrient balance of at least $60 \mathrm{~kg} \mathrm{~N} / \mathrm{ha}, 20 \mathrm{~kg} \mathrm{P} / \mathrm{ha}$ and $30 \mathrm{~kg} \mathrm{~K} / \mathrm{ha}$ (Brady and Weil, 2002). While nutrient deficiencies still occur in some fields a greater majority of soils have experienced a nutrient build up (Bergstrom et al., 2005). Inherently infertile soils require external inputs of fertilizer materials for sustained fertility and productivity, especially under continuous cropping (Nyathi and Campbell (1997). The root cause of declining fertility is land degradation manifested in form of soil fertility depletion, especially under smallholder farming sector (Stoorvogel and Smaling, 1990; Smaling et al., 1997) and nutrient imba-lance on large scale farms (Nandwa and Bekunda, 1998).

Evidences and indicators of soil fertility decline in West Africa include appearances of widespread distribution of soils deficient in major macro-nutrients and micro-nutrients (ascertained from commensurate crop responses and soil analyses and local soil quality indicators), and widespread negative nutrient balances (Bationo et al., 1998). The predominantly sandy soils in northeast semi-arid Nigeria renders their management strategies less effective as a result of their low water holding capacity and low organic matter content. Soil fertility management has to focus on supplying inputs from external sources to improve organic matter content of soils and consequently its capacity as a repository for nutrients. Chemical fertilizers are the obvious sources to counter balance the nutrient depletion, but unfortunately there are few local sources of manufactured fertilizers. Because of the great distances over which imported fertilizers must be transported, their farm-delivered price is at least twice the international price (Brady and Weil, 2002). The presently high cost of chemical fertilizers coupled with unfavorable crop/fertilizer price ratios discourages their additions, especially in smallholder farms. Therefore, innovative combinations of organic and inorganic nutrient sources are to be used in order to increase nutrient inputs and to recycle the nutrients once they reach the soil. This suggests that part of the problem of nutrient deficiencies can be addressed through judicious use of organic inputs. Nyathi and Campbell (1997) found that synergism (complementary) existed when combinations of inputs to sandy soil included inorganic fertilizers, while studying the efficacy of combinations of organic and inorganic sources of nutrients. Bationo et al. (1998) also recognized the beneficial effect of continuous application of FYM along with mineral fertilizers on sandy loam soils. This research become imperative in documenting implementable information for farmers in this study area, considering the prevailing sharp nutrient decline trends evident in the region as a result of continuous cultivation without nutrient replacement. Therefore this paper is aimed at establishing optimum levels of combination of organic and inorganic nutrient sources to be applied to fertility decline.

\section{MATERIALS AND METHODS}

A field study was conducted on farmers field at Dusuman village (Latitude $11^{\circ} 50.82^{\prime} \mathrm{N}$ and Longitude $13^{\circ} 11.01^{\prime} \mathrm{E}$; 320 meters above sea level) of Jere Local Government area of Borno state during 2005 rainy seasons. The aim of this study was to determine the partial nutrient balance on farmers' field. The site has an average monthly temperature of 28.5 to $32.8^{\circ} \mathrm{C}$ in normal years and rainfall of $525 \mathrm{~mm}$ with typical savanna grassland vegetation. The soil characterization was carried out prior to treatment application.

The experiment consisted of nine treatments laid out in a randomized complete block design (RCBD) and replicated three times. The treatments comprised of a control, 2.5 tones of FYM + $\mathrm{N}_{60} \mathrm{P}_{30} \mathrm{~K}_{30} \mathrm{~kg} / \mathrm{ha}$ or $\mathrm{N}_{30} \mathrm{P}_{15} \mathrm{~K}_{15} \mathrm{~kg} / \mathrm{ha}$, 5.0 tones FYM $+\mathrm{N}_{60} \mathrm{P}_{30}$ $\mathrm{K}_{30} \mathrm{~kg} / \mathrm{ha}$ or $\mathrm{N}_{30} \mathrm{P}_{15} \mathrm{~K}_{15} \mathrm{~kg} / \mathrm{ha}, 7.5$ tones $\mathrm{FYM}+\mathrm{N}_{60} \mathrm{P}_{30} \mathrm{~K}_{30} \mathrm{~kg} / \mathrm{ha}$ or $\mathrm{N}_{30} \mathrm{P}_{15} \mathrm{~K}_{15} \mathrm{~kg} / \mathrm{ha}, 7.5$ tones $F Y M$ and $\mathrm{N}_{60} \mathrm{P}_{30} \mathrm{~K}_{30} \mathrm{~kg} / \mathrm{ha}$.

The land was manually cleared and harrowed with tractor driven disc. Three rows of nine plots were manually prepared using hand hoe. Each plot measured $5 \times 10 \mathrm{~m}$, making a total of twenty seven plots. Farmyard manure (FYM) was procured in the University of Maiduguri animal farm and applied to the plots according to the treatment levels, two weeks before planting. Chemical fertilizer in the form of compound NPK 15-15-15 was procured in the open market and applied according to the treatments. Samples of the FYM (Appendix 1) and the fertilizers were taken for nutrient content analyses. Seeds of pearl millet variety SOSAT-C-88 were dressed with Apron Star 42 WS at the rate of $10 \mathrm{~g}$ sachet per $4 \mathrm{~kg}$ seeds for protection against soil and seed borne pests and diseases and planted in the plots at a row spacing of $0.75 \mathrm{~m}$ apart and $0.5 \mathrm{~m}$ between stands in a row. Later after two weeks of planting (2 WAP) millet plants were thinned to three per stand. Plots were kept weed free manually at four weeks intervals. The plants were harvested after reaching physiological maturity stage.

Composite soil samples were collected prior to treatment application and again after harvest (post harvest samples), then crushed, sieved through $2 \mathrm{~mm}$ sieve and analyzed for N,P and K contents. Total $\mathrm{N}$ was determined using kjeldahl digestion method (Bremner and Mulvaney, 1982); available P using Bray-1 method (Olsen and Sommers, 1982) and exchangeable $\mathrm{K}$ using $\mathrm{NH}_{4} \mathrm{OAc}$ method (AOAC, 1970).

Plant samples which included straw and grain at harvest were also collected and analyzed for N, P and $\mathrm{K}$ contents (AOAC, 1970) as well as uptake. Budgeted method (Nandwa, 2003) was used to compute the partial nutrient balances from the data analyzed. The balances were determined using the differences between the inputs (mainly from chemical fertilizer and FYM) and the outputs (from crop residues, grain and soil). All data collected were subjected to Analysis of Variance (ANOVA) using statistix 8.0 (Statistix, 2005) Analytical Software package. Differences between treatment means were compared using Duncan Multiple Range Test (DMRT) at 5\% level of probability.

\section{RESULTS AND DISCUSSION}

The results of some physical and chemical properties of soil of the experimental site are presented in Table 1. The soil was low in fertility considering the low levels of organic matter $(3.80 \mathrm{~g} / \mathrm{kg})$, total $\mathrm{N}(0.40 \mathrm{~g} / \mathrm{kg})$ and available $\mathrm{P}(2.92 \mathrm{mg} / \mathrm{kg})$. In addition, the predominantly 
Table 1. Physico-chemical characteristics of soil of the experimental site.

\begin{tabular}{lc}
\hline Soil characteristics & Value \\
\hline $\mathrm{pH} 1: 2.5\left(\mathrm{H}_{2} \mathrm{O}\right)$ & 6.69 \\
$\mathrm{pH} 1: 2.5(\mathrm{KCl})$ & 4.80 \\
$\mathrm{EC}(\mathrm{dS} / \mathrm{m})$ & 0.04 \\
Organic carbon $(\mathrm{g} / \mathrm{kg})$ & 2.20 \\
Total N $(\mathrm{g} / \mathrm{kg})$ & 0.40 \\
$\mathrm{C}: \mathrm{N}$ ratio & 5.50 \\
Available P (Bray 1, mg/kg) & 2.92 \\
& \\
\hline Exchangeable cations (ammonium acetate, $\mathbf{c m o l} / \mathbf{k g})$ \\
\hline $\mathrm{Ca}$ & 3.60 \\
$\mathrm{Mg}$ & 2.80 \\
$\mathrm{~K}$ & 0.46 \\
$\mathrm{Na}$ & 0.05 \\
$\mathrm{H}+\mathrm{Al}$ & 0.80 \\
$\mathrm{CEC}$ & 7.71 \\
Base saturation (\%) & 89.62 \\
& \\
\hline Particle size distribution (\%) & \\
\hline Sand & 76.6 \\
Silt & 6.4 \\
Clay & 17.0 \\
Soil textural class & Sandy loam \\
\hline
\end{tabular}

Table 2. Nutrient balance of a millet cropping system grown under rain fed condition.

\begin{tabular}{lccc}
\hline \multirow{2}{*}{ Treatment } & \multicolumn{3}{c}{$\mathbf{~ g g} / \mathbf{h a} /$ year } \\
\cline { 2 - 4 } & $\mathbf{N}$ & $\mathbf{P}$ & $\mathbf{K}$ \\
\hline Control & $-43.41^{\mathrm{h}^{*}}$ & $-1.54^{\mathrm{h}}$ & $-61.17^{\mathrm{b}}$ \\
$2.5 \mathrm{t} \mathrm{FYM}+\mathrm{N}_{30} \mathrm{P}_{15} \mathrm{~K}_{15} \mathrm{~kg} / \mathrm{ha}$ & $-44.70^{\mathrm{h}}$ & $+15.22^{\dagger}$ & $-86.68^{\dagger}$ \\
$2.5 \mathrm{t} \mathrm{FYM}+\mathrm{N}_{60} \mathrm{P}_{30} \mathrm{~K}_{30} \mathrm{~kg} / \mathrm{ha}$ & $-26.55^{\mathrm{g}}$ & $+29.86^{\mathrm{b}}$ & $-108.69^{\mathrm{h}}$ \\
$5.0 \mathrm{t} \mathrm{FYM}+\mathrm{N}_{30} \mathrm{P}_{15} \mathrm{~K}_{15} \mathrm{~kg} / \mathrm{ha}$ & $-8.84^{\dagger}$ & $+18.55^{\mathrm{e}}$ & $-74.66^{\mathrm{e}}$ \\
$5.0 \mathrm{t} \mathrm{FYM}+\mathrm{N}_{60} \mathrm{P}_{30} \mathrm{~K}_{30} \mathrm{~kg} / \mathrm{ha}$ & $+23.95^{\mathrm{b}}$ & $+31.03^{\mathrm{b}}$ & $-45.32^{\mathrm{c}}$ \\
$7.5 \mathrm{t} \mathrm{FYM}+\mathrm{N}_{30} \mathrm{P}_{15} \mathrm{~K}_{15} \mathrm{~kg} / \mathrm{ha}$ & $+2.43^{\mathrm{d}}$ & $+20.95^{\mathrm{d}}$ & $-53.66^{\mathrm{d}}$ \\
$7.5 \mathrm{t} \mathrm{FYM}+\mathrm{N}_{60} \mathrm{P}_{30} \mathrm{~K}_{30} \mathrm{~kg} / \mathrm{ha}$ & $+27.15^{\mathrm{a}}$ & $+36.16^{\mathrm{a}}$ & $-21.43^{\mathrm{b}}$ \\
$7.5 \mathrm{t} / \mathrm{ha} \mathrm{FYM}$ & $+19.00^{\mathrm{c}}$ & $+7.87^{\mathrm{g}}$ & $-6.60^{\mathrm{a}}$ \\
$\mathrm{N}_{60} \mathrm{P}_{30} \mathrm{~K}_{30} \mathrm{~kg} / \mathrm{ha}$ & $-2.40^{\mathrm{e}}$ & $+27.18^{\mathrm{c}}$ & $-96.24^{\mathrm{g}}$ \\
$\mathrm{SE} \pm$ & 0.886 & 0.770 & 1.909 \\
\hline
\end{tabular}

*Values followed by the same letter(s) within a column are not significantly different from each other at $\mathrm{P}(<0.05)$ according to Duncan Multiple Range Test (DMRT).

millet farms in order to tackle the problems of soil sandy loam soil texture in the area predisposes any amendments to reduce effectiveness because of their low water holding capacity as evidenced from the dominant sand fraction and low organic matter content (Table 1). Soil fertility management that focused on supplying inputs from external sources will improve organic matter content and consequently its capacity to supply essential plant nutrients.

\section{Nutrient balances}

The estimated N, P and K balances for the millet based cropping system are presented in Table 2. The balances were estimated using inputs from the applied fertilizers and the output by the crop (Appendix 2 and 3). Treatment effect showed variation in all the balances estimated. N-balance was most negative (-44.70 $\mathrm{kg} / \mathrm{ha} /$ year) with $2.5 \mathrm{t} \mathrm{FYM} / \mathrm{ha}+\mathrm{N}_{30} \mathrm{P}_{15} \mathrm{~K}_{15} \mathrm{~kg} / \mathrm{ha}$. Increasing fertilizer levels subsequently increased the $\mathrm{N}$-balances. The highest effect $(+27.15 \mathrm{~kg} / \mathrm{ha} /$ year $)$ was obtained with $7.5 \mathrm{t} \mathrm{FYM/ha}+\mathrm{N}_{60} \mathrm{P}_{30} \mathrm{~K}_{30} \mathrm{~kg} / \mathrm{ha}$ which was significant $(P<0.05)$ when compared with the sole $7.5 t$ $\mathrm{FYM} /$ ha. Although, this highest value ought to have been more, leaching effect of the sandy soil and microbial decomposition might have reduced the value to this level. The recommended sole FYM level (7.5 $\mathrm{t} /$ ha) gave positive balance $(+19.00 \mathrm{~kg} / \mathrm{ha} /$ year $)$ unlike the sole $\mathrm{N}_{60} \mathrm{P}_{30} \mathrm{~K}_{30} \mathrm{~kg} / \mathrm{ha}$, which gave negative balance ($2.40 \mathrm{~kg} / \mathrm{ha} /$ year). The estimated results for the nutrient balance indicated that $\mathrm{N}$-balances were negative with lower levels of treatment application; however, increasing the rates of NPK and FYM increased the $\mathrm{N}$ balances. The negative balances with lower application rates might be attributed to crop uptakes as well as losses through leaching and soil erosion as a result of sandy nature of the soils. Rego et al. (2002) also reported similar cases with sandy soils of India. While the positive balance with the higher application rates could be attributed to the left over after satisfying microbial demand and crop uptake.

P-balance for all the fertilizer treated plots gave positive balances (Table 2), unlike the non P-treated plots. The FYM applied perhaps contained substantial amounts of Jama and Mafongoya (1999) reported that loss of $P$ from soil will be minimal if application involved organic incorporation. Estimated K-balances revealed negative balances with all the treatments, indicating soil $\mathrm{K}$ mining. $\mathrm{K}$ accumulated in the millet straw was much more than the applied rates, and this probably accounts for the K negative balances. Olk and Cassman (1993) similarly reported a net decrease in amount of $\mathrm{K}$ fixed in manure plots than in control plots and this explains why the treatments with higher combination rates had higher negative $\mathrm{K}$ balances than the untreated ones.

\section{Grain yields}

Mean millet grain yield from different fertilizer treatments are shown in Table 3. The highest yield $(2440 \mathrm{~kg} / \mathrm{ha})$ was obtained with the application of $7.5 \mathrm{t}$ $\mathrm{FYM} / \mathrm{ha}+\mathrm{N}_{60} \mathrm{P}_{30} \mathrm{~K}_{30} \mathrm{~kg} / \mathrm{ha}$ and the lowest $(789 \mathrm{~kg} / \mathrm{ha})$ 
Table 3. Effect of FYM and NPK fertilizer on pearl millet grain yield $(\mathrm{kg} / \mathrm{ha})$.

\begin{tabular}{|c|c|}
\hline Treatment & Mean grain yield (kg/ha) \\
\hline Control & $789^{f^{*}}$ \\
\hline $2.5 \mathrm{t} F Y M+\mathrm{N}_{30} \mathrm{P}_{15} \mathrm{~K}_{15} \mathrm{~kg} / \mathrm{ha}$ & $1703^{\text {de }}$ \\
\hline $2.5 \mathrm{t} F Y M+\mathrm{N}_{60} \mathrm{P}_{30} \mathrm{~K}_{30} \mathrm{~kg} / \mathrm{ha}$ & $1930^{\mathrm{cd}}$ \\
\hline 5.0 t $F Y M+N_{30} P_{15} K_{15} \mathrm{~kg} / \mathrm{ha}$ & $1978^{\mathrm{bcd}}$ \\
\hline 5.0 t $F Y M+N_{60} P_{30} K_{30} \mathrm{~kg} / \mathrm{ha}$ & $2065^{b c}$ \\
\hline 7.5t FYM + $\mathrm{N}_{30} \mathrm{P}_{15} \mathrm{~K}_{15} \mathrm{~kg} / \mathrm{ha}$ & $2301^{a b}$ \\
\hline $7.5 \mathrm{t} F Y M+\mathrm{N}_{60} \mathrm{P}_{30} \mathrm{~K}_{30} \mathrm{~kg} / \mathrm{ha}$ & $2440^{a}$ \\
\hline 7.5t/ha FYM & $1433^{\mathrm{e}}$ \\
\hline $\mathrm{N}_{60} \mathrm{P}_{30} \mathrm{~K}_{30} \mathrm{~kg} / \mathrm{ha}$ & $1970^{\mathrm{bcd}}$ \\
\hline $\mathrm{SE} \pm$ & 111.7 \\
\hline
\end{tabular}

* Values followed by the same letter(s) within a column are not significantly different from each other at $P(<0.05)$ according to Duncan Multiple Range Test (DMRT).

with the control. Application of FYM alone gave a significantly $(P<0.005)$ lower yield compared with the application of the combined fertilizer treatments. This shows the beneficial effect of combined nutrient application. The highest yield associated with the highest application rate represents about $20 \%$ increase over non application. Application of $7.5 \mathrm{t} \mathrm{FYM/ha} \mathrm{together}$ with sub-optimal mineral fertilizer could maintain soil fertility under continuous cropping system and consequently improve the nutrient balance as reported by Kwari et al. (1998), even though this huge amount is a constrain in this region. In addition, resource poor farmers might not be able to afford the cost of the recommended rates of mineral fertilizers. Therefore, combination of FYM and NPK fertilizers at the rates of $2.5 \mathrm{t} \mathrm{FYM} / \mathrm{ha}+\mathrm{N}_{30} \mathrm{P}_{15} \mathrm{~K}_{15} \mathrm{~kg} / \mathrm{ha}$ could be beneficial as revealed by this present study. Tabo (1995) also reported similar case of achieving higher grain yield of $1420 \mathrm{~kg} / \mathrm{ha}$ with the application of $2.5 \mathrm{t} \mathrm{FYM}+32 \mathrm{~kg}$ $\mathrm{N} / \mathrm{ha}$.

\section{Conclusion}

Application of lower levels of FYM in combination with NPK fertilizer could be more economical than either sole FYM or NPK. However, the performance of millet was better with the application of higher rates of combined application of FYM and NPK (7.5 t FYM/ha + $\mathrm{N}_{60} \mathrm{P}_{30} \mathrm{~K}_{30} \mathrm{~kg} / \mathrm{ha}$ ). Hence, application of lower levels of farmyard manure in combination with half the recommended rates of NPK fertilizer (2.5 t FYM/ha + $\mathrm{N}_{30} \mathrm{P}_{15} \mathrm{~K}_{15} \mathrm{~kg} / \mathrm{ha}$ ) for millet over a period of time will reduce nutrient depletion, increase nutrient balance and maintain sustainable crop production.

\section{REFERENCES}

Association of Official Analytical Chemists (AOAC) (1970). Official methods of analysis, Ed II. Washington, D. C.

Bationo A, Lompo F, Koala S (1998). Research on nutrient flows and balances in West Africa: State - of - the - Art. Agr. Ecosys. Environ. 71:21-38.

Bergstrom L, Bowman BT, Sims JT (2005). Definition of sustainable and unsustainable issues in nutrient management of modern agriculture. Soil Use Manage. 21:76-81.

Brady NC, Weil RR (2002). The nature and properties of soils $\left(13^{\text {th }}\right.$ Ed.). Prentice-Hall, Inc. New Jersey, U.S.A. pp. 199-223.

Bremner JM, Mulvaney CS (1982). Total N. In: Page, A. L. (ed.). Methods of soil analysis part 2. Chemical and mineralogical properties ( $2^{\text {nd }}$ ed). Agron. Monograph. ASA-SSSA, Madison, Wisconsin, USA 9:595-622.

Gichuru MP, Bationo A, Swift MJ (2003). Preface Note. In: Gichuru MP, Bationo A, Bekunda MA, Goma HC, Mafongoya PK, Mugendi DN, Murwira HM, Nandwa SM, Nyathi P, Swift MJ (Eds.). Soil Fertility Management in Africa: A Regional Perspective. Academic Science Publications. Nairobi, Kenya. pp. 147-186.

Jama BA, Mafongoya PL (1999). Strategies for soil fertility recapitalization in Africa: Experiences from Western Kenya and Eastern Zambia. In: FAO proceedings on soil fertility initiative in sub-Saharan Africa.

Kwari JD, Grema AK, Bibinu ATS (1998). Fertilizer trials for millet/legume mixtures with emphasis on nitrogen rates. In: Emechebe AM, Ikwelle MC, Ajayi O, Aminu-Kano M, Anaso AB (eds.). Pearl millet in Nigerian Agriculture: Production, Processing and Research priorities. Proceedings of the pre-season national coordination and planning meeting of the Nationally Coordination Research Programme on pearl millet. Lake Chad Research Institute, Maiduguri, Nigeria.

Nandwa SM, Bekunda MA (1998). Research on nutrient flows and balances in east and southern African: State-of-the-art. Agr. Ecosys. Envi. 71:5-18.

Nandwa SM (2003). Perspectives on Soil fertility in Africa. In: Gichuru MP, Bationo A, Bekunda MA, Goma HC, Mafongoya PK, Mugendi DN, Murwira HM, Nandwa SM, Nyathi P, Swift MJ (Eds.). Soil Fertility Management in Africa: A Regional Perspective. Academic Science Publications. Nairobi, Kenya. pp. 1- 50.

Nyathi P, Campbell BM (1995). Interaction effects of tree leaf, manure and inorganic fertilizer on the performance of maize in Zimbabwe. Afr. Crop Sci. J. 3(4):451-456.

Olk DC, Cassman KG (1993). Reduction of potassium fixation by organic matter in vermiculitic soils. In: Mulongoy $\mathrm{K}$, Merckx R (eds.). Soil Organic Matter Dynamics and Sustainability of Tropical Agriculture. A Wiley-Sayce Co-publication, IITA/K.U. Leuven. pp. 307-315.

Olsen SR, Sommers LE (1982). Phosphorus. In: Page AL (ed.). Methods of soil analysis part 2. Chemical and microbiological properties ( $2^{\text {nd }}$ ed). Agron. monograph. ASA-SSSA, Madison, Wisconsin, USA. 9:401-430.

Rego TS, Seeling B, Nageswara RV, Pardhasaradhi G, Kumar RJVDK, Myers RJK, Johansen C (2002). Nutrient balances: A guide to improving the sorghum and groundnut-based dry land cropping systems in semi-arid tropical India. In: Adv-Gyamfi JJ (ed.). Food security in nutrient-stressed environments: Exploiting plants' genetic capabilities. Kluwer Academic Publishers, The Netherlands. pp. 301-311.

Sanchez PA, Shepherd KD, Soule MJ, Place FM, Buresh RJ, Izac AMN, Mokwunye AU, Kwesiga FR, Ndiritu CG, Woomer PL (1997). Soil fertility replenishment in Africa: An investment in natural resource capital, In: Buresh RJ, Sanchez PA, Calhoun F (Eds.). Replenishing Soil fertility in Africa. SSSA Special publication, No.51. Madison, Wisconsin, USA.

Smaling EMA, Nandwa SM, Janssen BH (1997). Soil Fertility in Africa is at stake. In: Buresh RJ, Sanchez PA, Calhoun F (eds.). Replenishing

Soil fertility in Africa. SSSA Special publications. SI. SSSA, Madison, Wisconsin.

Statistix (2005). Statistical Software Analytical Package, Version 8.0, Cary, USA

Stoorvogel JJ, Smaling EMA (1990). Assessment of soil nutrient depletion in Sub-Saharan Africa: 1983-2000. Vol (I) Main report. 
The Winand Staring Centre. Wageningen, The Netherlands.

Tabo R (1995). Performance of sorghum and millet varieties under varying combinations of animal manure and chemical fertilizer. In: ICRISAT and collaborative programmes. West and Central Africa.
Annual Report (1995). International Crops Research Institute for Semi- Arid Tropics. pp. 53-54. 
Appendix 1. Nutrient content of FYM applied to the field.

\begin{tabular}{cc}
\hline Nutrient & Value (\%) \\
\hline $\mathrm{N}$ & 1.05 \\
$\mathrm{P}$ & 0.14 \\
$\mathrm{~K}$ & 1.28 \\
\hline
\end{tabular}

Appendix 2. Effect of FYM and NPK fertilizers on N, P and $\mathrm{K}$ uptake $(\mathrm{kg} / \mathrm{ha})$ by pearl millet leaves grown under rainfed condition, 2004 cropping season.

\begin{tabular}{lccc}
\hline Treatment & $\mathbf{N}$ & $\mathbf{P}$ & $\mathbf{K}$ \\
\hline Control & $30.85^{\mathrm{d}^{*}}$ & $1.46^{\mathrm{c}}$ & $8.85^{\mathrm{d}}$ \\
$2.5 \mathrm{t} \mathrm{FYM}+\mathrm{N}_{30} \mathrm{P}_{15} \mathrm{~K}_{15} \mathrm{~kg} / \mathrm{ha}$ & $93.40^{\mathrm{bc}}$ & $3.69^{\mathrm{bc}}$ & $21.01^{\mathrm{bc}}$ \\
$2.5 t \mathrm{FYM}+\mathrm{N}_{60} \mathrm{P}_{30} \mathrm{~K}_{30} \mathrm{~kg} / \mathrm{ha}$ & $134.09^{\mathrm{ab}}$ & $4.76^{\mathrm{ab}}$ & $25.39^{\mathrm{ab}}$ \\
$5.0 \mathrm{t} \mathrm{FYM}+\mathrm{N}_{30} \mathrm{P}_{15} \mathrm{~K}_{15} \mathrm{~kg} / \mathrm{ha}$ & $115.55^{\mathrm{abc}}$ & $5.03^{\mathrm{ab}}$ & $22.55^{\mathrm{bc}}$ \\
$5.0 \mathrm{t} \mathrm{FYM}+\mathrm{N}_{60} \mathrm{P}_{30} \mathrm{~K}_{30} \mathrm{~kg} / \mathrm{ha}$ & $120.84^{\mathrm{abc}}$ & $3.86^{\mathrm{b}}$ & $24.04^{\mathrm{ab}}$ \\
$7.5 \mathrm{t} \mathrm{FYM}+\mathrm{N}_{30} \mathrm{P}_{15} \mathrm{~K}_{15} \mathrm{~kg} / \mathrm{ha}$ & $137.85^{\mathrm{ab}}$ & $7.04^{\mathrm{a}}$ & $26.40^{\mathrm{ab}}$ \\
$7.5 \mathrm{t} \mathrm{FYM}+\mathrm{N}_{60} \mathrm{P}_{30} \mathrm{~K}_{30} \mathrm{~kg} / \mathrm{ha}$ & $159.17^{\mathrm{a}}$ & $6.46^{\mathrm{a}}$ & $31.47^{\mathrm{a}}$ \\
$7.5 \mathrm{t} / \mathrm{ha} \mathrm{FYM}$ & $81.85^{\mathrm{c}}$ & $3.26^{\mathrm{bc}}$ & $15.21^{\mathrm{cd}}$ \\
$\mathrm{N}_{60} \mathrm{P}_{30} \mathrm{~K} \mathrm{~K}_{30} \mathrm{~kg} / \mathrm{ha}$ & $78.97^{\mathrm{cd}}$ & $5.05^{\mathrm{ab}}$ & $21.43^{\mathrm{bc}}$ \\
$\mathrm{SE} \pm$ & 16.926 & 0.777 & 2.638 \\
\hline
\end{tabular}

* Values followed by the same letter(s) within a column are not significantly different from each other at $P$ $(<0.05)$ according to Duncan Multiple Range Test (DMRT).

Appendix 3. Effect of FYM and NPK fertilizer on N, P and $\mathrm{K}$ uptake $(\mathrm{kg} / \mathrm{ha})$ by pearl millet grain grown under rainfed condition in the field, 2004 cropping season.

\begin{tabular}{lccc}
\hline Treatment & $\mathbf{N}$ & $\mathbf{P}$ & $\mathbf{K}$ \\
\hline Control & $51.99^{\mathrm{f}^{*}}$ & $2.41^{\mathrm{e}}$ & $37.92^{\mathrm{d}}$ \\
$2.5 \mathrm{t} \mathrm{FYM}+\mathrm{N}_{30} \mathrm{P}_{15} \mathrm{~K}_{15} \mathrm{~kg} / \mathrm{ha}$ & $128.99^{\mathrm{bc}}$ & $4.70^{\mathrm{c}}$ & $84.82^{\mathrm{abc}}$ \\
$2.5 \mathrm{t} \mathrm{FYM}+\mathrm{N}_{60} \mathrm{P}_{30} \mathrm{~K}_{30} \mathrm{~kg} / \mathrm{ha}$ & $127.74^{\mathrm{bc}}$ & $5.68^{\mathrm{b}}$ & $105.05^{\mathrm{a}}$ \\
$5.0 \mathrm{t} \mathrm{FYM}+\mathrm{N}_{30} \mathrm{P}_{15} \mathrm{~K}_{15} \mathrm{~kg} / \mathrm{ha}$ & $108.28^{\mathrm{d}}$ & $4.62^{\mathrm{c}}$ & $71.25^{\mathrm{bc}}$ \\
$5.0 \mathrm{t} \mathrm{FYM}+\mathrm{N}_{60} \mathrm{P}_{30} \mathrm{~K}_{30} \mathrm{~kg} / \mathrm{ha}$ & $122.81^{\mathrm{c}}$ & $4.82^{\mathrm{c}}$ & $81.77^{\mathrm{abc}}$ \\
$7.5 t \mathrm{FYM}+\mathrm{N}_{30} \mathrm{P}_{15} \mathrm{~K}_{15} \mathrm{~kg} / \mathrm{ha}$ & $141.35^{\mathrm{ab}}$ & $5.70^{\mathrm{b}}$ & $90.72^{\mathrm{ab}}$ \\
$7.5 t \mathrm{FYM}+\mathrm{N}_{60} \mathrm{P}_{30} \mathrm{~K}_{30} \mathrm{~kg} / \mathrm{ha}$ & $151.62^{\mathrm{a}}$ & $6.37^{\mathrm{a}}$ & $103.59^{\mathrm{a}}$ \\
$7.5 \mathrm{t} / \mathrm{ha} \mathrm{FYM}$ & $76.08^{\mathrm{e}}$ & $3.04^{\mathrm{de}}$ & $59.43^{\mathrm{cd}}$ \\
$\mathrm{N}_{60} \mathrm{P}_{30} \mathrm{~K} \mathrm{~K}_{30} \mathrm{~kg} / \mathrm{ha}$ & $99.54^{\mathrm{d}}$ & $3.37^{\mathrm{d}}$ & $76.52^{\mathrm{bc}}$ \\
$\mathrm{SE} \pm$ & 4.750 & 0.215 & 8.917 \\
\hline
\end{tabular}

* Values followed by the same letter(s) within a column are not significantly different from each other at $\mathrm{P}(<0.05)$ according to Duncan Multiple Range Test (DMRT). 